\title{
Teacher's Suggestions for Recycling and Sustainable Environment: Reflections on Diaries ${ }^{1}$
}

\author{
Assoc. Prof. Dr. Dilek Erduran Avci \\ Mehmet Akif Ersoy Universitiy, Education Faculty, Science Education Department, Burdur, Turkey \\ dilek924@gmail.com
}

\author{
Assist. Prof. Dr. Huriye Deniş Çeliker \\ Mehmet Akif Ersoy Universitiy, Education Faculty, Science Education Department, Burdur, Turkey \\ huriyedenis@mehmetakif.edu.tr
}

\section{Doi:10.5901/jesr.2015.v5n1s1p203}

\section{Abstract}

There has been great increase in the amount of waste as a result of consumption habits of humankind. Having a sustainable environment is possible by recycling and providing the reuse these wastes. But it is encountered with some conditions which may negatively affect all living creatures because of leaving wastes into the nature without any process. Education of sustainable environment has a key role in reducing these problems. Science is one of the lessons which may give this education in Turkey. In this view science teachers should have a well-informed, conscious and positive attitude about subjects of recycling and sustainable environment. Based on this matter, a project named "look forward and recycle: Recyclist teacher" was performed. This project was actualized in Burdur between 17-23 August 2014 with the support of the Scientific and Technological Research Council of Turkey (TÜBITAK) and Mehmet Akif Ersoy University. Totally 23 activities were applied within the project. During this process, teachers who attended this project kept diaries about assigned subjects when they completed their activities. Diary subjects were determined in a way to allow participants for expressing their feelings and thoughts related with the activity content of each day. Throughout five days, suggestions of participants for recycling and sustainable environment in written diaries were analyzed. When diaries are examined it is seemed that suggestions of science teachers are collected under five main categories for recycle and sustainable environment. These are precautions on the basis of state, economic extent, education, written and visual media, and precautions on the basis of nature. Results of research are considered to be a guide for future works.

Keywords: teacher's suggestions, recycling, sustainable environment, diaries

\section{Introduction}

People and environment they live in are an inseparable whole. People's interaction with nature is inevitable within the scope of this wholeness. But this interaction has been turning solution into tough problem when it is unidirectional for only human interests without considering nature (Kocatas, 2003). It is remarkable that struggle between human and nature will turn into power struggle between ecology and economy and as a result of these people will eventually destroy themselves (Atasoy, 2006). The negative effects of human activities on nature are increasing rapidly (Yıldız, Sipahioğlu and Yılmaz, 2005; Kışlalıoğlu and Berkes, 2003). People, who think that consumption will especially increase life quality, have been consuming much more (Kilbourne, 2006), the more consumption increases the more waste increases and it will cause more environmental pollution. Wastes, which are one of the causes of these negative effects, have grown to such an extent that they threaten the lives of our generation and the future generations (Güler and Çobanoğlu, 1994; Özek, 1994; Ongley,1996).

Recycling which is one of the most important attitude for environment is the process that puts various waste materials (glass, paper, aluminum, cell, motor oil, accumulator, concrete, organic wastes and electronic wastes etc. ) into recycling by turning into secondary material with various physical and/or chemical treatments (Buyuksaatci, Kucukdeniz,

${ }^{1}$ Data of this work was prepared during the process of the project Look Forward and Recycle: Recyclist Teacher with the number 213B704 that was supported within the scope of TÜBITAK (The Scientific And Technological Research Council Of Turkey) 4004 Nature and Science Schools in 2014. 
and Esnaf, 2008). Recycling contributes to protection of natural sources in environment and to reducing the amount of solid waste. Recycling contributes as economically and environmentally besides reducing the amount of solid waste (Oom Do Valle, Reis, Menezes, and Rebelo, 2004). Consequently it is seemed as an important part of sustainable future (Hopper and Nielsen, 1991; Oskamp, 1995; Valle, Reis, Menezes, and Rebelo, 2004).

According to expressions of Kaya and Tomal (2011) in their works, sustainability was used for the first time as political and economic concept in 18th century by Georg Ludwig Harting. The concept was described as "sustainable use of resources" in Rio de Janeiro United Nations World Environment Summit Meeting in 1992. In the sense of protecting environment the sustainability can be described as displaying attitude which can keep environment in its most natural shape, and being in activities of recycling environment which is damaged or vanished as a result of human activities (Yavuz, 2010). Sustainable development has been addressed both economic growth and ecological balance and been described as being attentive to provide future generations' necessities in today without risking their necessities in the future (Karalar and Kiraci, 2011).

Sustainable environment and efficient recycling can only be obtained by focusing on educated consumption attitudes. Individuals have duties and responsibilities in reducing the amount of wastes, separating wastes from its sources and recycling. This can only be managed by individuals with conscious, sensitive and awareness (Karatekin, 2003).

Education has an important role in raising individuals with conscious, sensitive and awareness about sustainable environment and recycling. Science class is one of those classes which this education may be given. In the sense of both vision indicated in the science class curriculum of Ministry of National Education (2013) and acquisitions in its content, Science class and science teachers have an important role in raising a generation adopted recycling. In order to perform this role science teachers should be well-informed and have positive attitude for waste and recycling. Because teachers have an important place in students' information source about recycling (Çimen and Yılmaz, 2012). Based on this, "Look Forward and Recycle: Recyclist Teacher" project, which was supported within the scope of Scientific and Technological Research Council of Turkey (STRCT) 4004 - Nature and Science Schools, was actualized by science teachers. The project comes to the forefront with an activity program including information and application of participants, as both individuals and teachers, about sustainable environment and recycling. The aim of this work is to present suggestions of science teachers, participated this project, for sustainable environment and recycling.

\section{Method}

This work is a qualitative research.

The participants comprise 20 science teachers who work in secondary schools from different provinces of Turkey. 13 female and 7 male teachers participated to the project. The participants were chosen according to the information they have provided on application form. In application form, participants were asked about their seniority, graduated school and department, province which they are living, whether allergic and chronic illness they have or not, what they think and what they do relating to waste and recycling, reasons why they want to get involved in this project. Participants were selected according to assessment criteria. Participants' willingness to participate in the project was also taken into consideration.

Teachers' diaries are used as data collection tool. Teachers' suggestions for recycling and sustainable environment are tried to be presented with a content analysis from their expressions in dairies. Themes and sub-themes obtained as a result of content analysis are supported by quoting teachers' expressions in diaries. Nicknames of participants are used instead of their names while quoting.

\subsection{The project of "Look forward and recycle: Recyclist teacher"}

"Look forward and recycle: Recyclist teacher" project was prepared for gaining this awareness and it was supported by TUBITAK 4004 Nature education and science schools'. Project conducted between 17-23 August 2014. The primary purpose of this project was to show the participants the effects of wastes on human, animals, plants and the others; by getting them to involve to the recycling activities. Another purpose of this project was to improve the scientific understanding of the participants on this subject and finally make them gain a positive attitude towards recycling.

In this project 23 different activities were carried out. These activities were "Meeting (creative drama), Is The Life Possible Without Waste?, Waste And Creative Abilities, Writing Time: Diary, Track Of Wastes, Biodegradation, How To Enable The Conversion Of Biodegradations, A Trip To Hobby Garden, Making Compost And Having Biogas, Effect Of 
Domestic And Agricultural Waste To The Lake, Livings Around The Water Resources I-II, Where Is Our Waste Going?, Designing Education Activities, Presentation And Discussion About Educational Activities Which Were Designed, A Trip to History I-II, We Remember Our Experience, Sharing Time.

During this process teachers wrote diaries about assigned subjects when they completed their activities. Diary subjects are determined in a way which allows participants for expressing their feelings and thoughts about activity content of each day. Diaries of participants are examined with respect to teachers' suggestions for recycling and sustainable environment.

\section{Findings}

When science teachers' suggestions for recycling and sustainable environment in diaries were examined, five main themes showed up. These themes are precautions on the basis of state, economic extent, education, written and visual media, and precautions on the basis of nature. In table-1 themes which took place in teachers' diaries and its distribution are given.

Table 1. Themes which took place in teachers' diaries and its dissemination with respect to recycling and sustainability.

\begin{tabular}{cc}
\hline \hline Themes & $\mathbf{N}$ \\
\hline \hline Precautions on the basis of state & 14 \\
\hline Economic extent & 14 \\
\hline Education & 13 \\
\hline Written and Visual Media & 7 \\
\hline Precautions on the basis of nature & 4 \\
\hline \hline
\end{tabular}

\subsection{Precautions on the basis of state}

Most of science teachers, participated the project activities, mentions about precautions on the basis of state for sustainable environment in their diaries. As regarding these precautions sub-categories are that penal sanction should be set, legal regulations should be made, incentive pays should be given, awarding should be actualized, recycling and sustainability should be turned into government policy. Some of the expressions in teachers' diaries are like:
As long as there are not hefty sentences, I do not think that waste problem will end. (Inci) In order to turn waste materials into energy industrialists should be promoted and facilities which will be established should be excised if it is necessary. (Doruk)
I think that amount of waste production should be reduced in order to solve Turkey's waste problem. I also consider this situation should be a government policy. (Ayse)
.... municipalities, district governorship, governorates and government should handle with this situation. Subjects related to recycling-regaining of environment and wastes should be in regulated constitution provisions. (Nil)
Factories which use wastes should be established in Turkey and these should be promoted with state incentives. (Meltem)
We should take this subject to parliament and present our suggestion to representatives. . Parliament should promote people by making law about this matter. (Okan).
Politicians may promote people to recycle their wastes by making legal regulations and establishing foundations to follow-up. People may earn some financial income with respect to their wastes or collecting wastes may be provided by presents. (Ilhan)
...Immigration from undeveloped nations should be prevented. Migrations which overburden cities should be prevented. (Zeki)
For example, just saying "recycling products such as plastic, glass, paper and cell should be collected in schools" is not enough. Collected wastes should be taken in periods by municipalities. (Gorkem)

\subsection{Economic extent}

Science teachers who are project participants emphasize on economic extent for providing recycling in aimed level and sustainable environment. An adequate budget is needed in order to provide enough recycling banks, to develop facility and systems of recycling, to support scientific research and projects related to the subjects. Some expressions of teachers related to economic extent are like: 
State institutions and organizations should be mobilized and enough recycling banks should be put in related places, adequate budget should be formed, and sanctions should be made. (Nehir)

If we arrange funds in environment projects for country wide person and organizations, we can promote them. (Orhan) Adequate containers of metal, glass, cell and domestic wastes should be put in neighborhoods. (Zehra)

Adequate budget should be formed in order to make recycling boxes, facilities, collect units, and facilities of wastewater utilization. (Ayse)

... interdisciplinary works and projects should be given an opportunity. (Ilhan)

Factories in which recycling materials can be recycled should be established in every city. (Hasan)

In schools, houses, workplaces, hospitals there should be enough waste boxes which we can categorize our wastes. (Gunay)

\subsection{Education}

Most of science teachers stated that education is important for sustainability. In education category they emphasized that there should be classes related to the subject, conscious consumption attitude should be developed, individuals should gain a habit to collect wastes separately, and community should become conscious. They also mentioned about educations of families, children, adults and moral educations. Some expressions of teachers about education are like:

Ending Turkey's garbage can only be possible with completing related education and lack of conscious. Community can only become conscious with education. (Evren)

People should be informed about waste material and how these materials damage environment. In this respect schools should be given education and if it is necessary "recycling classes" should be arranged. (Doruk)

I firstly say that education is an obligation to solve this problem. (Ayse)

Ending garbage is possible by informing people... Informing people and especially students is so important. (Inci)

All people should become conscious. (Damla)

Families should be informed about recycling. (Meltem)

In our country citizens should become conscious from early ages. (Zeliha)

We can start our struggle by ending garbage in the head of children in home and students in school. After they became conscious we had already brought solutions slowly. Our children produce so original ideas that I believe they will start the biggest development. In time, people, families will become conscious. After the country will become conscious and there will not be garbage or waste problem in Turkey. (Gunay)

The biggest lack in the management of waste is unconsciousness of families. As a beginning families should become conscious and applications should be made about this matter. When these applications became a habit, it would reflect on children. There may be a lesson about environmental consciousness and children can be informed about this subject. (Munevver)

...it should be told that being happy with consumption is not normal. (Irmak)

Students should be informed not to use gift package and people should be promoted to use rummage materials. Open buffet, all in systems should be either removed or limited. (Hasan)

\subsection{Written and Visual Media}

Some of science teachers who are project participants emphasize on the importance of written and visual media for recycling and sustainable environment. In this view, they stated that press, social media, poster, public services or cartoons may be used, campaigns may be arranged, and also advertisements including negative consumption attitudes should be avoided. Some of teachers' suggestion expressions for written and visual media are like following:

...cartoons should be used to educate young in this way. Very popular cartoon hero would be a good garbage collector. In this way a community who collect garbage will come out. (Damla)

In houses and streets precautions which are galvanizer for separating wastes should be taken. For this purpose written and visual media can be benefitted. (Meltem)

Several people are not even aware of how wastes, they threw, pollute environment. So awareness should be created by putting up a poster where people can easily see. (Ilhan)

Public service ad and reading texts in the books should be used in order to make people conscious. (Gunay)

Campaigns may be initiated ("develop your neighborhood with your own waste") like building park, astroturf, wedding saloon for neighborhood. Treeplanting campaigns: build your own forest. Just like a tree for a kilo of cell, a tree for a kilo of metal, bring paper and take your tree. (Zehra)

...by creating awareness a consciousness can be created on people about recycling through putting up posters at where people may see. (Orhan) 
...reducing pollution may be provided by maintaining campaigns until creating a conscious. (Gorkem)

\title{
3.5 Precautions on the basis of nature
}

Few of science teachers offered suggestions for sustainable environment with precautions on the basis of nature such as creating protection zones, protecting water sources, planting plants which do not consume much water. Some expressions of teacher are below:

\begin{abstract}
Planting plants which do not need much water like rose, levanter will be so useful to the process. (Ayse)
Water sources should not be hired to companies for income, city wastes should not be left on the way of these sources. (Inci) ...protection areas should be created. (Ibrahim)
\end{abstract}

\section{Results and Discussion}

When diaries of teachers, who participated the project "Look Forward and Recycle: Recyclist Teacher" and wrote throughout the project, are examined, their suggestions related to recycling and sustainable environment are collected under five main categories: (1) precautions on the basis of state, (2) economic extent, (3) education, (4) written and visual media, (5) precautions on the basis of nature. Legal regulations, laws and common policies, serving services such as mass transportation and collecting containers for recycling, reaching opportunity for eco-friendly alternative products, role of environmentalist groups in social consciousness, advertisements, press and news about the subject can be counted between exterior sustainable factors which affect individual attitudes (Kilbourne et al. , 2002; Stern, 2000). As a result of analysis which science teachers presented, it is seemed that content of reached categories and sub-categories includes exterior factors which effect individual attitudes mentioned above.

For sustainable environment and recycling most of science teachers emphasized on precautions on the basis of state that penal sanctions should be set, legal regulations should be made, incentive pays should be given, awarding should be actualized, recycling and sustainability should be turned into government policy. When the effects and necessities of public support on creating aimed effect of legal regulations such as sanctions, penalties and taxations which is applied to reduce overconsumption of sources within property are considered, the importance of role of local governments under environmental management comes again to forefront (Sengul, 2002; Brown and Cameron, 2000). Local governments contribute to protecting and healing environment by providing attendance of individuals into environmental management (Üste, 2005). Örten (2009) listed down the main duties of local governments on individual consumption attitudes as: creating environmental consciousness, presenting required substructure services, following up incentive policies and performing legal sanctions. A sustainable system consists of political responsibility and attendance (Holmberg and Sandbrook, 1992). As regarding legal regulations and sustainable government policy Colakoglu (2010) emphasized that countries' creating unique environment right in national constitutes and giving this right a place is important for sustainable environment. When it is considered that sustainable environment is connected with sustainable consumption; Veenhoven (2004), who said that sustainable consumption both takes place in political decision making bodies and is a fact based on convincing consumers with powerful tool, emphasized on the importance of decision makers. According to Cooper et al. (1998), governments can direct consumption attitudes of individuals with campaigns, services, incentives or sanctions aimed at individuals as well as providing an environmental development on consumption attitudes as a result of legal sanctions they applied. As a result of meetings which is made to present the role of local governments on individual sustainable consumption, Örten (2009) stated that they indicated the necessity of making laws and consolidating penal sanctions in order to prevent individual attitudes caused pollution and damaged environment after given required education to people about environment and constituted substructure. Correspondingly science teachers emphasized on penal sanctions and legal regulations. Some of science teachers state that immigration which overburdens cities and countries should be prevented and increasing of population is something negative for sustainability. In other words Schaefer and Crane (2005) stated that the rate of increase in population should be reduced as a way of reducing high rate in consumption.

Again most of science teachers emphasized on economic extent for providing recycling at aimed level and sustainable environment. An adequate budget is needed for providing enough recycling banks, developing recycling facilities and systems, supporting scientific research and project related to the subject.

Another factor which science teachers emphasize for sustainable environment is education. They emphasized that there should be classes about environmental education, conscious consumption attitude should be developed, 
individuals should gain a habit to collet wastes separately and people should become conscious. They also mentioned about education of families, children, adults and moral education as related do the subject. Education is an important extent for sustainable environment when it is considered that environmental education is important to understand habits such as understanding, skill, attitude and thought about environment, to understand natural relations took place between human, society and natural systems and to know how we can make these relations more sustainable, and this system consists of the process which is being successfully active, helps to make right decisions about environment and turns these decisions into eco-friendly attitudes (O'Brien, 2007; Kışoğlu, 2009). One of the subcategories of education, which came out as a result of teachers' suggestions, is to develop a conscious consumption attitude. Consumption habits of individuals who constitute the society directly or indirectly cause the consumption of natural sources and deterioration of ecological environment (Munksgaard et al. , 2002). In order to make people gain sustainable consumption habits Karalar and Kiraci (2010) mentioned about implementations as product sharing systems should be created, individuals should be encouraged to display sharing habits against buying products, recycling boxes should be put in several places of city, we should be organized to collect used dresses, book etc. , bicycle roads should be built in the city. It is seemed that there are some similar examples between science teachers' suggestions. It is seemed that teachers' expressions about making people conscious are parallel with expressions of Karatas and Aslan (2012) that family, education organizations, mass communication tools and nongovernmental organizations have important roles in developing environmental conscious.

A part of science teachers who are project participants emphasized on written and visual media for recycling and a sustainable environment. At this stage, they have indicated that press, social media, posters, public service ads or cartoon films can be used and campaigns can be formed. They also indicated that advertisements including negative consumption attitudes should be prevented. Such as to support the using of written and visual media Selanik Ay (2010) stated that students' benefiting from media product in gaining environmental conscious contributes to having information about environment, to gain environmental conscious, to develop their skills in searching, to realize environmental issues, to keep them being up to date, to make learning process an interesting thing, and to increase their sensitiveness to environment. Alim (2006) stated that according to the result of a research made in the United States of America students in primary and middle schools gets their environmental information mostly from written and visual media, then school and last their family and friends. The role of written and visual media on environmental education which science teachers emphasized in their suggestions has been presented also by researches. According to Barkan and Eroglu (2004), educators use written and visual media in education process in order to make learning permanent. There are hundreds of works which tests educational values of pictures, television, slide, film strip, records and other educational media. The results obtained from these tests, effective using of these kind of media has a great value in education process. Although science prospective teachers indicated the positive aspect of written and visual media, they have also mentioned to avoid from advertisements including negative consumption attitudes. Karalar and Kiraci (2011) emphasized the negative effects of advertisements by stating that cultural norms, created with the support of advertisement, cause to make wrong decisions in consumption which is based upon lack and partial information of consumers.

A few of science teachers offered suggestions for sustainable development with precautions on the basis of nature such as creating protection areas, protecting water sources and planting plants which do not need much water. One of the important points of sustainable consumption is that we need to provide our necessities in today by considering the opportunities of next generations to provide their own necessities without overconsuming natural sources and destroying environment (Mortensen, 2006). Sustainable consumption means reducing used natural sources and protecting in developed countries at least (Cooper, 2005).

As a result of this work, most of suggestions which reflect on diaries of science teachers, participated the project about recycling and sustainable environment, are parallel with related literature in great parts. It is considered that research results will be pathfinder for new works. Also research results may be examined by executive units, education organizations, parents, written and visual media organizations.

Several works present that projects have positive effects (Erduran Avcı, Deniş Çeliker, 2015; Balkan Kıyıcı, Atabek Yiğit, Selcen Darçın, 2014; Balım, Deniş Çeliker, Türkoğuz and Kaçar, 2013; Tekbıyık, Şeyihoğlu, Sezen Vekli and Birinci Konur, 2013; Karataş and Aslan, 2012; Cappellaro, Ünal Çoban, Akpınar, Yıldız and Ergin, 2011; Erdoğan, 2011; Keleş, Uzun and Varnacl, 2010; Güler, 2009; Ozaner, 2004).

In this sense, performing projects with the content of sustainable environmental education is important. It is obvious that a necessity giving an importance to nature education projects, which are supported by various organizations to develop regaining with recycle and to create a sustainable natural environment, comes out (Erdogan, 2011; Ulucinar Sagir, Aslan and Cansaran, 2008). It can be stated that similar projects with teacher-centered whose aims are to raise 
next generations or with different participant in its center should be actualized and disseminated in order to provide important gains.

\section{References}

Alım, M. (2006). Environment and environmental education in primary school in turkey within the process of the membership of European union, Kastamonu Education Journal, 14 (2), 599-616.

Atasay, E. (2006). Çevre için eğitim ve çocuk doğa etkileşimi, Ezgi Kitapevi Yayınları, Bursa.

Balım, A. G. , Deniş Çeliker, H. , Türkoğuz, S. , \& Kaçar, S. (2013). The effect of reflections of science on nature project on students' science process skills, Journal of Research in Education and Teaching, 1 (2), 149-157.

Barkan, M. , \& Eroğlu, E. (2004). Eğitim iletişiminde çağdaş ortamlar: iletişim bir sorun kaynaği mi yoksa çözüm seçeneği mi?. The Turkish Online Journal of Educational Technology, 3 (3), 115-123.

Balkan Kıyıcı, F. , Atabek Yiğit, E. , \& Selcen Darçın, E. (2014). Investigation of Pre-Service Teacher's Opinion and Environmental Literacy Level Change with Nature Education, Trakya University Journal of Education, 4 (1), 17-27.

Büyüksaatçı, S. , Küçükdeniz, T. , \& Esnaf, Ş. (2008). Determining location of recycling plants with gustafsonkessel algorithm-convex programming hybrid model-based simulation. İstanbul Ticaret Üniversitesi Fen Bilimleri Dergisi, 7 (13), 1-20.

Brown, P. M. , \& Cameron, L. D. (2000). What can be done to reduce overconsumption?. Ecological Economics, 32 (1), $27-41$.

Cappellaro, E. ,Ünal Çoban, G. ,Akpınar,E. ,Yıldız, E. , \& Ergin,Ö. (2011). Yetişkinler için yapılan uygulamalı çevre eğitimine bir örnek: su farkındalığı eğitimi, Journal of Turkish Science Education, 8 (2), 157-173.

Cooper, P. J. , Brady, L. P. , Hidalgo-Hardeman, O. , Hyde, A. , Naff, K. C. , Ott, S. J. , \& White, H. (1998). Public administration for the twenty-first century. USA: Harcourt Brace \& Company.

Cooper, T. (2005). Slower consumption reflections on product life spans and the "throwaway society", Journal of Industrial Ecology, 9 (12), 51-67.

Çolakoğlu, E. (2010). Haklar söyleminde çevre eğitiminin yeri ve Türkiye'de çevre eğitiminin anayasal dayanakları. TBB Dergisi, 88, 151171.

Çimen, O. , \& Yılmaz, M. (2012). Recycling knowledge, behaviors, and attitudes of primary school students, Journal of Uludag University Faculty of Education, 25 (1), 63-74.

Erdoğan, M. (2011). The effects of ecology-based summer nature education program on primary school students' environmental knowledge, environmental affect and responsible environmental behavior, Educational Sciences: Theory \& Practice, 11 (4), 2223-2237.

Erduran Avcı, D. , \& Deniş Çeliker, H. (2015). The effect of recycler teachers project on scince teachers' attitude towards waste and recycling. Journal of Research in Education and Teaching. 4 (1), 215-224.

Güler Ç. , \& Çobanoğlu Z. , (2004). Katı atıklar, T. C. sağlık bakanlığı sağlık projesi koordinatörlüğü yayını, Çevre Sağlığı Temel Kaynaklar Dizisi No: 29, Ankara.

Güler,T. (2009). The Effects of an Ecology Based Environmental Education on Teachers' Opinions about Environmental Education, Education and Science, 34 (151).

Holmberg, J. , \& Sandbrook, R. (1992). Sustainable development: what is to be done? Making development sustainable: redefining Institutions, policy, and economics. (Ed. J. Holmberg). International Institute for Environment and Development, s. 19-38, Washington, D. C. Island Press.

Hopper, J. R. , \& Nielsen, J. M. (1991). Recycling as altruistic behavior: Normative and behavioral strategies to expand participation in a community recycling program, Environment and Behavior, 23 (2), 195-220.

Karalar, R. , \& Kiraci, H. (2010). A research on class teachers related to determining the effects of consumers' personal values on sustainable consumption behavior. İşletme Araştırmaları Dergisi, (2), 79-106.

Karalar, R. , \& Kiracı, H. (2011). Sustainable consumption notion as a solution to ecological problems, Dumlupınar University Journal of Social Sciences, 30, 63-76.

Karataş, A. , \& Aslan, G. (2012). The role of environmental education in gaining environmental awareness for elementary school students: the sample of ecology based summer camp project, Zeitschrift für die Welt der Türken/Journal of World of Turks, 4 (2), 259-276.

Karatekin, K. (2013). Developing a scale to measure pre-service teachers' attitudes towards solid waste and recycling: a validity and reliability study, International Eurasian Journal of Social Sciences, 4 (10), 71-90.

Kaya, M. F. \& Tomal, N. (2011). Examination of the social sciences education program in the frame of sustainable development training, Journal of Educational Sciences Research, 1 (2), 49-65.

Keleş, Ö. , Uzun,N. \& Varnacı, (2010). The change of teacher candidates" environmental consciousness, attitude, thought and behaviors with nature training project and the assessment of its permanence, Electronic Journal of Social Sciences, 9 (32), 384 401.

Kışlalıoğlu, M. \& Berkes, F. (2003). Ekoloji ve çevre bilimleri. Remzi Kitabevi. Büyük Fikir Kitapları Dizisi: 95. İstanbul.

Kışoğlu, M. (2009). Investigation of the effect of the teachers of the student-centered teaching environmental literacy levels, Unpublished doctoral dissertation, Atatürk University, Institute of Science: Erzurum.

Kilbourne, W. E. , Beckmann, S. C. , \& Thelen, E. (2002). The role of dominant social paradigm in environmental attitudes: A 
multinational examination, Journal of Business Research, 55, 193-204.

Kilbourne, W. (2006). The role of the dominant social paradigm in the quality of life/environmental interface, Applied Research in Quality of Life, 1, 39-61.

Kocataş, A. (2003) Ekoloji ve çevre biyolojisi, Sekizinci Baskı, Ege Üniversitesi Basımevi, Bornova, İzmir.

Milli Eğitim Bakanlığı. (2013). Fen bilimleri dersi öğretim programı. Ankara: Talim ve Terbiye Kurulu Başkanlığı.

Mortensen, L. F. (2006). Sustainable household consumption in Europe?, Consumer Policy Review, 16 (4), 141.

Munksgaard, J. , Wier, M. , Lenzen, M. , \& Dey, C. (2002). Indicators for the environmental pressure of consumption. Life-cycle Approaches to Sustainable Consumption Workshop Proceedings, Interim Report, International Institute for Applied Systems Analysis, Laxenburg, Austria. (p. 171). [Online]Available: file: ///C: /Users/pb6570b/Downloads/0f317531e28271d001000000\%20 (1). pdf (February 27, 2015).

O'Brien, S. R. M. (2007). Indications of environmental literacy: using a new survey instrument to measure awareness, knowledge and attitudes of university aged students. Unpublished master thesis, lowa State University: Iowa.

Ongley, E. D. (1996). Control of water pollution from agriculture. FAO Irrigation And Drainage, 55, Roma.

Oom Do Valle, P. , Reis, E. , Menezes, J. , \& Rebelo, E. (2004). Behavioral determinants of household recycling participation the: Portuguese case, Environment and Behavior, 36 (4), 505-540.

Oskamp, S. (1995). Resource conservation and recycling: Behavior and policy. Journal of Social Issues, 51 (4), $157-177$.

Ozaner, S. (2004). Türkiye'de okul dışı çevre eğitimi ne durumda? neler yapılmalı? V. Ulusal Ekoloji ve Çevre Kongresi, Abant İzzet Baysal Üniversitesi \& Biyologlar Derneği, Bolu.

Özek, E. (1994). Environmental pollution from agriculture and simulation studies. Unpublished master thesis, Ankara Üniversitesi Fen Bilimleri Enstitüsü: Ankara.

Örten, T. (2009). The role of individual sustainable consumption behavior of local governments. Cumhuriyet University Faculty of Arts and Social Sciences Journal, 33 (2), 197-204.

Schaefer A. , \& Crane A. (2005). Addressing sustainability and consumption, Journal of Macromarketing, 25 (1), 76-92.

Selanik Ay, T. (2010). Sosyal bilgiler dersinde çevre bilinci kazandırmada medya ürünlerinden yararlanmaya ilişkin öğrenci görüşleri. International Eurasian Journal of Social Sciences, 1 (1), 76-93.

Stern, P. C. (2000). Toward a coherent theory of environmentally significant behavior. Journal of Social Issues, 56 (3), $407-424$.

Şengül, M. (2002). Çevre yönetimine halk katılımı yolu olarak belediye yönetimine halk katılımı. Çağdaş Yerel Yönetimler Dergisi, 11 (2), 25-40.

Tekbıyık, A. , Şeyihoğlu, A. , Sezen Vekli, G. , \& Birinci Konur, K. (2013). Influence of a science camp based on active learning on students, International Journal of Social Science. 6 (1); 1383-1406.

Uluçınar Sağır, Ş. , Aslan, O. , \& Cansaran, A. (2008). The examination of elementary school students' environmental knowledge and environmental attitudes with respect to the different variables. Elementary Education Online, 7 (2), 496-511.

Üste, R. B. (2005). Yerel yönetimlerde demokratikleşme. Türk İdare Dergisi, 448, 49-60.

Valle, P. , Reis, E. , Menezes, J. , \& Rebelo, E. (2004). Behavioral determinants of household recycling participation. Environment and Behavior, 36 (4), 505-540.

Veenhoven, R. (2004). Sustainable consumption and happiness, driving forces and barriers to sustainable consumption, International Workshop, University of Leeds. [Online] Available: http://www2.eur.nl/fsw/research/veenhoven/Pub2000s/2004d-full. pdf (February 16, 2015).

Yavuz V. A. (2010). Concept of sustainability and sustainable production strategies for business practices, Mustafa Kemal University Journal of Social Sciences Institute, 7, 63-86.

Yıldız, K. , Sipahioğlu, Ş. , Yılmaz, M. . (2007). Environmental science and education. Türkiye. Gündüz Eğitim ve Yayıncılık. 
ISSN 2239-978X

ISSN 2240-0524
Journal of Educational and Social Research MCSER Publishing, Rome-Italy
Vol. 5 No.1 S1 April 2015 